\title{
The Impact of Emotional Intelligence on Employee Work Engagement Behavior: An Empirical Study
}

\author{
Dr. K. Ravichandran \\ Assistant Professor, School of Management, New York Institute of Technology \\ Abu Dhabi Campus, UAE \\ E-mail: varshal2@yahoo.com \\ Dr. R. Arasu (Professor and Head) \\ PG Department of Management Sciences- MBA, Velammal Engineering College \\ Velammal nagar, Ambattur -Redhills Road, Chennai-600 066, India \\ E-mail: profarasu@gmail.com \\ S. Arun Kumar \\ Assistant Professor, Department of Management Studies \\ Saranathan College of Engineering, Trichy, Tamilnadu, India \\ E-mail: arunkanthh@yahoo.co.in
}

Received: June 15, 2011

Accepted: July 18, $2011 \quad$ Published: November 1, 2011

doi:10.5539/ijbm.v6n11p157

URL: http://dx.doi.org/10.5539/ijbm.v6n11p157

\begin{abstract}
Although EI has become a popular tool in organizations there is still a need for increased empirical research on the construct (Salovey, Woolery, \& Mayer, 2002). This study contributes to the literature by providing more information about Emotional intelligence which may alleviate Work Engagement Behavior. It does this by building on the small existing pool of knowledge in order to extend the research on EI. The expected outcome of this study was an increased understanding of how EI impacts on Work Engagement Behavior. Emotional intelligence was measured using the 33-item Schutte Self-Report Inventory (SSRI) developed by Schutte and colleagues (Schutte et al, 1998). Engagement was measured using the shortened version of the Utrecht Work Engagement Scale (UWES) (Schaufeli et al., 2006). The scale consists of 9 items and was designed to measure the three components of engagement: vigor, absorption, and dedication. The samples of 119 employees who are from information technology services and Information technology enabled services of Chennai city in India, chosen for the study. Self Administered questionnaire distributed and information collected. Research design descriptive type with non probability purposive sampling technique was used for the study. The data were analyzed using SPSS (statistical package for social science) version 14. The statistical tools like Cronbach's Alpha Reliability Test, Correlation, Chi - Square Test, One - Way ANOVA, Post - Hoc Test, Factor Analysis and Regression Analysis were employed for the research study. From these Research Findings, managerial as well as theoretical implications have been discussed in this study.
\end{abstract}

Keywords: Emotional intelligence, Work engagement behavior, Schutte Self-Report Inventory (SSRI), Utrecht Work Engagement Scale (UWES)

\section{Introduction}

Emotional Intelligence refers to the ability to perceive, control, and evaluate emotions. Emotional Intelligence plays an important role in helping the managers and employees to cope with this dynamic change in the business environment. Some researchers suggest that emotional intelligence can be learned and strengthened, while other claim it is an inborn characteristic. Employees need to enhance their emotional intelligence skills, apart from technical skills, which in turn will enhance their productivity on the job. Management of emotional intelligence by the team members will help in developing interpersonal skills of the team members. Organization's to be successful, need to develop employee's emotional intelligence skills to work effectively in the organization, Emotional Intelligence in modern organizations induce energetic and dedicated employees: people who are engaged with their work. These organizations expect proactive, initiative and responsibility for personal development from their employees. Motivating people to engage in their work is a classic problem in organizations, complicated by the existence of multiple roles, because the attitudes, behaviors, and emotions associated with one role may spill over to another. People do not always check their problems or triumphs at the door when walking into the office or coming home from work. Moreover, as careers have become more complex, people are increasingly faced with actively engaging in multiple roles. Within the context of the organization, 
people often must engage in multiple roles to fulfill job expectations which can be fulfilled by Emotional Intelligence. Hence this study tries to explore the relationship between Emotional Intelligence Construct and Work Engagement Behavior which really implicate the managerial and organization performance.

\section{Research objectives}

- To study the Demographic and Rational profile of IT (Information Technology) \& ITES (Information Technology Enabled Services) Employees.

- To understand the linear association between the Emotional Intelligence and Work Engagement behavior.

- To identify the dominant variables of Emotional Intelligence which influence the Work Engagement behavior?

- To find out the underlying extracted dimensions of Emotional Intelligence construct.

\section{Research Review}

Although definitions for EI vary, it can generally be described as an individual's ability to assess the emotions of oneself and others, to accurately express and regulate one's emotions, and finally to use this information to direct thoughts and actions (Mayer, Salovey, \& Caruso, 2000). The aim of this section is to provide support for this statement through a thorough review of the EI construct. The most prevalent EI models will be explored and the current debate in the literature concerning the appropriateness of the different EI models and measures will be examined. The concept of intelligence is often associated with general mental ability, however several researchers have suggested that intelligence is a multifaceted construct incorporating several types of abilities. In the early twentieth century, Thorndike suggested three types of intelligence that were distinct from cognitive ability Thorndike, 1920 cited in (Kihlstrom \& Cantor, 2000). The three types were called abstract, mechanical, and social intelligence (Thorndike, 1920 cited in Kihlstrom\& Cantor, 2000) Abstract intelligence involves the comprehension and management of thought, while mechanical intelligence requires being able to understand tangible objects (Thorndike, 1920 cited in Kihlstrom\& Cantor, 2000). However, it is social intelligence that is most closely related to EI (Kihlstrom\& Cantor, 2000 Social intelligence involves the capacity to understand and get along with other people (Thorndike, 1920 cited in Kihlstrom \& Cantor, 2000). A large component of EI concerns the ability to understand emotions as they relate to one's self and others. The two concepts overlap because they both involve the skill of being able to understand others.

Towards the end of the twentieth century, Gardner also proposed a theory of multiple intelligences that incorporated skills and capabilities that went beyond those associated with cognitive abilities (Gardner, 1983 cited in Schutte et al, 1998). Two of the intelligences that Gardner proposed were known as the personal intelligences. The first is the concept of interpersonal intelligence and it closely relates to both Thorndike's concept of social intelligence and EI in that it involves the ability to understand others (Gardner, 1983 cited in Goleman, 1995). The second is known as intrapersonal intelligence and it entails being introspective or developing an understanding of one's own motivations and feelings (Gardner, 1983 cited in Goleman, 2005). Both intrapersonal intelligence and EI involve skills that require the individual to draw on being able to understand themselves and their emotions at an in-depth level. By incorporating similar ideas and concepts, the EI construct builds directly on the work of theoreticians such as Thorndike and Gardner (Salovey\& Mayer, 1990) Although academicians Salovey and Mayer (1990) were the first to use the term EI, the concept was extensively popularized through the writings of Daniel Goleman (2005) in his widely read book Emotional Intelligence (Landy, 2005; Matthews et al., 2002) Popular interest in the topic has become so great that it appears to have surpassed the empirical research. In a search of the Psyclnfo database, Landy (2005) found 102 citations related to EI in empirical journals in a twenty year period from 1985 to 2005, and speculated that the number of cites in non-empirical journals would be much larger. Many claims were made in the popular press regarding the power of EI, but supporting empirical evidence is lacking (Landy, 2005; Matthews et al., 2002). For example, Goleman (2005) implies that EI might be more influential than IQ (Mayer, Salovey, \& Caruso, 2004 Later a cover story in the weekly news magazine Time, repeated this claim suggesting that EI may be more important in predicting success than IQ or other measures of cognitive abilities (Gibbs, 1995). However, the supporting research for these types of claims is often proprietary and not publicly available. There is a clear rift between the popular and academic conceptualizations of EI, with one side making broad claims and the other asking for restraint (Landy, 2005). This rift magnifies the large gap in the literature concerning EI research and can only be brought to a close with further investigation of the EI construct. By investigating EI as a moderating variable, this study attempts to address this hole in the literature by adding to the empirically based information available regarding EI.

\subsection{Models of Emotional Intelligence}

Currently, there are several competing models of EI in the literature. The two principal models are known as the ability and mixed models. The primary focus of ability models is relating mental ability to EI (Mayer et al.,

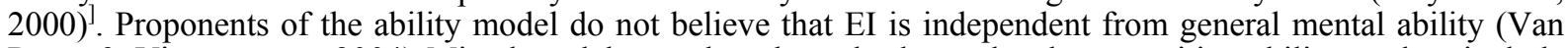
Rooy \& Viswesvaran, 2004) Mixed-models are thought to be less related to cognitive ability, and to include certain personality traits (Mayer et al., 2000; Van Rooy\&Viswesvaran, 2004).

The three main conceptualizations of EI, representing both the ability and mixed models will now be reviewed in greater depth. The ability model is most closely associated with the work of Mayer, Salovey, and Caruso (Mayer et al, 2004; Salovey\& Mayer, 1990; Salovey et al, 2002). It consists of four main skills which will now be 
discussed in turn.

- The first skill involves the ability to perceive and appraise emotion. This skill entails the individual being able to accurately assess and experience their emotions. It also requires that individuals be adapt at assessing the emotions of others and attributing emotions to objects (e.g. artwork).

- The second skill concerns assimilating emotion into thought. One component of this skill involves using emotions to guide thinking and focus attention. A second component entails using emotion to aid one's judgment and memory, and relies to some extent on the expression of emotion occurring according to certain rules (Mayer et al., 2000). For example, anger may occur in a situation that is deemed unfair, but happiness is not as likely to occur in that same situation. In this scenario the individual would need to understand what types of emotions normally occur in similar situations and may rely on past memories to assist their judgment.

- The third skill, understanding and analyzing emotion, involves recognizing the rules of emotional expression and being able to appropriately label emotions.

- Finally, emotion regulation involves being able to assess and adjust one's mood and the mood of others. An individual using this skill may be able to make his/her own anger subside or be of assistance in pacifying others who are upset.

Emotional intelligence was measured using the 33-item Schutte Self-Report Inventory (SSRI) developed by Schutte and colleagues (Schutte et al, 1998) The SSRI is a well known measure of emotional intelligence (Brackett \& Mayer, 2003). The measure is based on the original theoretical work of Salovey and Mayer (1990) on emotional intelligence. The developers began with a pool of 62 items, but through the use of factor analysis reduced the number of items to the current 33. Using factor analysis they initially extracted four factors, but determined that a single factor solution best fit the data. The authors of the scale found Cronbach's alpha of .90 in a community based sample and .87 in a student based sample (Schutte et al., 1998). Test retest reliability covering a two-week period was found to be .78 (Schutte et al., 1998)

The SSRI was found not to be related to cognitive ability as measured by SAT math and verbal scores (Schutte et al, 1998). In terms of personality, although the original developers found that the measure was only related to the openness dimension of the NEO Personality Inventory (Schutte et al, 1998), the results of subsequent studies have offered different results. In addition to openness, researchers have found that the SSRI correlates with extraversion, agreeableness, and conscientiousness (Brackett \& Mayer, 2003; Saklofske et al., 2003). The scale was negatively correlated with loneliness and depression (Saklofske et al., 2003). One group of researchers did demonstrate that the SSRI has discriminant validity by showing that when personality was controlled, correlations between the measure and outcome variables were smaller but still significant (Saklofske et al., 2003).

The one factor solution proposed by the scale developers has been criticized. Several researchers have reanalyzed the factor analytics of the scale and determined that a four factor solution that more closely correspond to the Mayer and Salovey (1990) model fit best (Petrides\&Furnham, 2000; Saklofske et al, 2003). Unfortunately, the detection of these factors has not been consistent, as not all researchers have been able to replicate this finding (Brackett \& Mayer, 2003). Here, in this study among the 33 variables, the researcher after content validity and pilot study with 20 respondents refined the 33 variables into 29 variables. The SSRI is a well known measure of emotional intelligence (Brackett \& Mayer, 2003). The measure is based on the original theoretical work of Salovey and Mayer (1990) on emotional intelligence here, in this study among the original 33 variables, the researcher after content validity and pilot study with 20 respondents refined the 33 variables into 29 variables. Another construct to test the interaction and relationship with EI, Work engagement behavior was taken which can be defined as a positive and satisfying state of mind (Schaufeli\& Bakker, 2004). When applying the term to the workplace, engagement can be described as involving positive feelings towards work and the job (Macey\& Schneider, 2008).

\subsection{Work Engagement}

Work Engagement can be defined as a positive and satisfying state of mind (Schaufeli \& Bakker, 2004). When applying the term to the workplace, engagement can be described as involving positive feelings towards work and the job (Macey \& Schneider, 2008). The construct connotes multiple meanings and incorporates a variety of concepts including but not limited to satisfaction, vigor, dedication, energy, job involvement, and organizational commitment (Macey\& Schneider, 2008). Research on engagement evolved from research on its polar opposite, the construct of burnout (Schaufeli, Salanova, Gonzalez-Roma, \& Bakker, 2002). This shift in the focus of researchers from the negative to the positive was largely influenced by the positive psychology movement (Schaufeli, Bakker, \&Salanova, 2006; Schaufeli et al., 2002). Positive psychology encourages researchers to attend to the positive qualities and strengths of humans instead of only focusing on psychopathology and maladjustment (Seligman \&Csikszentmihalyi, 2000). By focusing on engagement, researchers are able to attend to the positive aspects of work as opposed to the negative aspects as in burnout.

Although no studies were found that directly related EI to engagement, two studies were identified that relate the use of job based resources to engagement. It is appropriate for these studies to be reviewed because within the context of the COR model, EI will be employed as a resource. The first study, based on a sample of Finnish teachers, demonstrated that job resources, (including but not limited to supervisor support, job control, and 
appreciation), reduced the effects of job demands, (in the form of student misbehavior), on work engagement (Bakker, Hakanen, Demerouti, \&Xanthopoulou, 2007). In other words, when the teachers were faced with a stressful situation, having resources protected their level of engagement from diminishing. In the second study, the authors were testing a model of burnout (Demerouti, Bakker, Nachreiner, \&Schaufeli, 2001). They did not study engagement directly, but instead investigated its converse, disengagement. The researchers found that job resources negatively related to disengagement from work. Given the finding from the first study, this result makes sense and indirectly supports the idea that job resources might protect engagement level from stress. An additional study was identified that related work and family with engagement. The author of the study was interested in investigating how the theories of depletion, (which claims that an individual has a fixed amount of resources), and enrichment, (which argues that having a large number of role commitments may be beneficial), affected engagement in work and family roles (Rothbard, 2001). The results of the study indicated that there were gender differences in the relationship between the management of the two domains and family and work engagement (Rothbard, 2001). The results revealed that family did not negatively influence work engagement for men, but for women work engagement was enhanced by family (Rothbard, 2001).

The first two studies provide support for the idea that job resources were related to engagement. This is significant because it lays the groundwork for proposing that EI as a resource could be related to engagement. The final study establishes that a relationship between the work family domains and engagement exists. This allows the current study to advance the literature by examining whether EI moderates this relationship. Although the gender differences in the work family study suggest that hypotheses could be investigated for both directions of WFC, the current study focused on just the WIF direction because of its higher frequency in the workplace.

Engagement was measured using the shortened version of the Utrecht Work Engagement Scale (UWES) (Schaufeli et al., 2006). The scale consists of 9 items and was designed to measure the three components of engagement: vigor, absorption, and dedication. The 7 point response scale ranged from never to always/every day. Sample items included: "At my work, I feel bursting with energy", "I am enthusiastic about my job," and "I feel happy when I'm working intensely" (Schaufeli et al., 2006). In a study across 10 countries, Cronbach's alpha for the scale was usually found to be above .80 (Schaufeli et al., 2006). Since the scale in its current version is fairly new, a review of the literature did not uncover many studies that have used the measure. However, one study that did use the shortened scale found that Cronbach's alpha was above .75 but did not report the specific coefficient for the UWES scale (Heuven, Bakker, Schaufeli, \&Huisman, 2006). In addition, the components of the shortened scale were highly correlated with the original scale with correlations between the two generally above .90 across the different countries. Test-retest reliability was measured in two countries, Australia and Norway, over a one year period. Coefficients for the three components ranged between .56 and .61 in Australia and were slightly higher in Norway where they ranged between .66 and .71 . The scale authors suggest that the total score for all 9 items of the scale be used as a measure of work engagement instead of calculating scores for the 3 different engagement components due to high correlations between the 3 components. The scale was appropriate for the current study because it measured all three aspects of engagement but was also short so it was not burdensome for participants to complete. Scale brevity was important in the current study because so many measures are being used.

\section{Results and Discussions}

\section{Insert Figure 1 - here}

\section{Insert Table 1 - here}

\subsection{Correlations}

4.1.1 Hypothesis

H0: There is no significant linear association between the Overall Emotional Intelligence behavior and Overall Work Engagement behavior.

H1: There is significant linear association between the Overall Emotional Intelligence behavior and Overall Work Engagement behavior.

\section{Insert Table 2 - here}

The above correlations table No.2 displays Pearson correlation coefficients, significance values, and the number of cases with non-missing values. Pearson correlation coefficients assume the data are normally distributed. The Pearson correlation coefficient is a measure of linear association between two variables. The values of the correlation coefficient range from -1 to 1 . The sign of the correlation coefficient indicates the direction of the relationship (positive or negative).

The absolute value of the correlation coefficient indicates the strength, with larger absolute values indicating stronger relationships. The correlation coefficients on the main diagonal are always 1.0, because each variable has a perfect positive linear relationship with itself. Correlations above the main diagonal are a mirror image of those below.

The absolute value (.377) of the correlation coefficient indicates positive weaker relationship between Overall Emotional Intelligence and Overall work Engagement.

\subsubsection{Reliability Statistics}

Insert Table 3 - here 
The alpha values were calculated to assess the internal consistency reliabilities of the Emotional Intelligence Construct. For Emotional Intelligence Construct, the results indicate a very good acceptable value of .907. Since, Item-to-total correlations exceeded 0.50 respectively by a wide margin.

\section{Insert Table 4 - here}

The alpha values were calculated to assess the internal consistency reliabilities of the Work Engagement Behavior. For Work Engagement Behavior, the results indicate a very good acceptable value of .920. Since, Item-to-total correlations exceeded 0.50 respectively by a wide margin.

\section{Insert Table 5 - here}

H0: There is no significant association between Work Experience and Employee motivates them by imagining a good outcome to tasks they take on.

H1: There is significant association between Work Experience and Employee motivate themselves by imagining a good outcome to tasks they take on.

A low significance value of .011 which is typically below 0.05 indicates that, there is significant association between employee work experience and employee motivates themselves by imagining a good outcome to tasks they take on.

\subsection{Hypothesis}

\section{Insert Table 6 - here}

H0: There is no significant difference between Work Experience with that of Employee motivates them by imagining a good outcome to tasks they take on.

H1: There is significant difference between Work Experience with that of Employee motivates them by imagining a good outcome to tasks they take on.

A low significance value of .002 which is typically below 0.05 indicates that, there is significant difference between employee work experience groups with that of employee motivates themselves by imagining a good outcome to tasks they take on.

\section{Insert Table 7 - here}

Dependent Variable: I motivate myself by imagining a good outcome to tasks I take on.

The table 7 lists the pair wise comparisons of the group means for all selected post hoc procedures. Mean difference lists the differences between the sample means. Significance lists the probability that the population mean difference is zero. A $95 \%$ confidence interval is constructed for each difference. If this interval contains zero, the two groups do not differ. It is observed from the above table there remains a difference between less than 1year experience group and 2 years experience group, one year and 2 years and more than 3 years and two years in determining Employee motivate themselves by imagining a good outcome to tasks they take on, which is clearly denoted by the ${ }^{*}$ mark in the mean difference column.

\section{Insert Table 8 - here}

Total Variance Explained exhibits the result of factor analysis with principal component analysis of 29 items of Emotional Intelligence were total variance explained with 8 factors were extracted out of 29 items and this has been confirmed by the Eigen value for the extracted factors were (9.175), (2.534), (1.783), (1.529), (1.433), $(1.265),(1.177)$, and (1.120) respectively greater than recommended level of 1.It is worth noted that the first factor explained a variance of 31.638 percent from the original set of items. Moreover, the eight factors explained a cumulative variance of 69.022 percent from the 29 Emotional Intelligence construct. Rotated component matrix shows the result of factor analysis with the extraction technique of principal component analysis as well as the rotated component matrix based on the varimax rotation technique with Kaiser Normalization. It is inferred that the researcher identified eight factors namely,

\section{Factor 1}

I use good moods to help myself keep trying in the face of obstacles; I easily recognize my emotions as I experience them; I motivate myself by imagining a good outcome to tasks I take on; I help other people feel better when they are down; When I am in a positive mood, I am able to come up with new ideas; When I am in a positive mood, solving problems is easy for me; I am aware of the non-verbal messages other people send and form Factor 1.

\section{Factor 2}

The variables Emotions are one of the things that make my life worth living; Some of the major events of my life have led me to re-evaluate what is important and not important; I expect that I will do well on most things I try; I am aware of my emotions as I experience them; I expect good things to happen; When I am faced with obstacles, I remember times I faced similar obstacles and overcame them; Other people find it easy to make known in me and form Factor 2.

Factor 3

The variables I am aware of the non-verbal messages I send to others; By looking at their facial expressions, I recognize the emotions people are experiencing; I present myself in a way that makes a good impression on 
others; When I experience a positive emotion, I know how to make it last; I seek out activities that make me happy and form Factor 3.

\section{Factor 4}

The variables I can tell how people are feeling by listening to the tone of their voice; I know when to speak about my personal problems to others and form Factor 4.

\section{Factor 5}

The variables namely when another person tells me about an important event in his or her life, I almost feel as though I have experienced this event myself; I know what other people are feeling just by looking at them and form Factor 5.

\section{Factor 6}

Variables namely I like to share my emotions with others and forms Factor 6.

\section{Factor 7}

Variables namely I know why my emotions change and forms Factor 7.

\section{Factor 8}

Finally, the variables namely it is difficult for me to understand why people feel the way they do and forms Factor 8 .

\section{Insert Table 9 - here}

The Table 9 Regression Model Summary table displays R, R Square, Adjusted R Square, and the standard error. $\mathrm{R}$ is the multiple correlation coefficient, is the correlation between the observed and predicted values of the dependent variables. In the model 5 the $\mathrm{R}$ value of .589 indicates the moderate relationship. $\mathrm{R}$ squared value of .347 indicates the proportion of variation in the dependent variable explained by the regression model. The $\mathrm{R}$ square moderate values indicate that the model fit the data satisfactorily. Adjusted $\mathrm{R}$ squared value of .318 attempts to correct $\mathrm{R}$ squared to more closely reflect the goodness of fit of the model in the population. The Unstandardized coefficients are the coefficients of the estimated regression model. The $t$ statistics can help to determine the relative importance of each variable in the model.

$$
\begin{array}{r}
\text { Multiple } \mathrm{R}=.589, \mathrm{~F}-\text { Value }=12.019 \text {, d.f }(5,113), \mathrm{P}-\text { Value }<0.01, \mathrm{R}^{2} \text { Value }=.347 \\
\mathrm{Y}=1.379+.428 \mathrm{X}_{1}+.272 \mathrm{X}_{2}+.352 \mathrm{X}_{3}+(-.242) \mathrm{X}_{4}+(-.156) \mathrm{X}_{5}
\end{array}
$$

The above equation shows the impact of the variables of Emotional Intelligence aspects such as, When employee experience a positive emotion, they know how to make it last; Employees arrange events others enjoy; Employees aware of the non-verbal messages other people send; Employees expect good things to happen; Employees know what other people are feeling just by looking at them; On the Work Engagement Behavior of IT and ITES Sector employees.

On an average if the variable namely When employee experience a positive emotion, they know how to make it last there will be .428 units increase in the Overall Work Engagement Behavior when other variables are kept constant. Moreover the result of the $t$ test confirms that the calculated partial regression coefficient, such as (.428), (.278), (.352), (-.242), and (-.156) are highly significant at 1 percent level and 5 percent level. Similarly the multiple $\mathrm{R}$ of 0.589 shows there exist a relationship of 58.9 percent between the variables of Emotional Intelligence and Overall Work Engagement. The R square value of 0.347 exhibits that, the variables of Emotional Intelligence explained a variation of 34.7 percent on the Overall Work Engagement. Finally the result of $f-$ test signifies that the explained variation by the above said variables in the Emotional Intelligence Constant was highly significant at 1 percent level.

From the above analysis it is concluded that the variables of Emotional Intelligence namely When employee experience a positive emotion, they know how to make it last; Employees arrange events others enjoy; Employees aware of the non-verbal messages other people send are the dominant variables which impact on the employee Work Engagement behavior.

\section{Conclusion \& Implication of the research}

Through the substantiation out of the research model \& hypothesis the study through correlation analysis proves the alternative hypothesis and rejects the null hypothesis there by there is a significant linear association between the Overall Emotional Intelligence and Overall Work Engagement behavior. It is critically observed the pearsons correlation co-efficient value of $.377(* *)$ indicates positive weaker relationship between the above said variables which is a reflection of Emotional Intelligence behavior alone will not influence Work Engagement behavior. Hence managers need to identify those variables which influence Work Engagement behavior apart from the existing Emotional Intelligence construct variables used for this study. Statistically by critical observation from post hoc test the study witnessed that there is a difference between the groups. That is there is a difference between "Less than 1 year and 2 Year", "1 year and 2 Year", "More than 3 year and 2 Year". Hence it is concluded that employee motivate themselves by imagining a good outcome to task that they take on. When their respective work experience of their job increases.As a managerial implication Work Experience play a crucial role in enhancing the Emotional Intelligence behavior. So future managers need to associate employee motivate themselves by imagining a good outcome to task that they take on and Work Experience while the deal with Emotional Intelligence behavior.Adequately the R square value indicate that the model fit the data is not up 
to the expected satisfactory level which should be normally .7 and above.Here from the study $\mathrm{R}$ square value of .347 only observed using stepwise multiple regression method.Hence the researcher need to explore other unidentified variables which enhance Work Engagement behavior.Managers can focus on the dominant variables of Emotional Intelligence construct namely, When employee experiences a positive emotion, they know how to make it last; Employees arrange events others enjoy; Employees aware of the non-verbal messages other people send is to enhance Work Engagement behavior.The factor analysis of the study extracts eight dimensions out of 29 variables in the research reviewed Emotional Intelligence construct.So managers need to focus on these eight Emotional Intelligence dimensions when they explore Emotional Intelligence study.

\section{References}

Bakker, A. B., Hakanen, J. J., Demerouti, E., \& Xanthopoulou, D. (2007). Job resources boost work engagement, particularly when job demands are high. Journal of Educational Psychology, 99(2), $274-284$. http://dx.doi.org/10.1037/0022-0663.99.2.274

Brackett, M. A., \& Mayer, J. D. (2003). Convergent, discriminant, and incremental validity of competing measures of emotional intelligence. Personality and Social Psychology Bulletin, 29(9), 1147-1158. http://dx.doi.org/10.1177/0146167203254596

Demerouti, E., Bakker, A. B., Nachreiner, F., \& Schaufeli, W. (2001). The job demands resources model of burnout. Journal of Applied Psychology, 86(3), 499-512. http://dx.doi.org/10.1037/0021-9010.86.3.499

Gibbs, N. (1995, October 2). The EQ factor. [Online] Available: http://www.time.com/time/magazine/article/0,9171,983503,00.html. (October 11, 2009)

Goleman, D. (1995). Emotional intelligence. New York: Bantam Books.

Goleman, D. (2005). Emotional intelligence. (10th Anniversary Edition ed.). New York: Bantam Books.

Heuven, E., Bakker, A. B., Schaufeli, W., \& Huisman, N. (2006). The role of self efficacy in performing emotion work. Journal of Vocational Behavior, 69(2), 222-235. http://dx.doi.org/10.1016/j.jvb.2006.03.002

Kihlstrom, J. F., \& Cantor, N. (2000). Social intelligence. In R. J. Sternberg (Ed.), Handbook of intelligence. New York: Cambridge University Press.

Landy, F. J. (2005). Some historical and scientific issues related to research on emotional intelligence. Journal of Organizational Behavior, 26(4), 411-424. http://dx.doi.org/10.1002/job.317

Macey, W. H., \& Schneider, B. (2008). The meaning of employee engagement. Industrial and Organizational Psychology, 7(1), 3-30. http://dx.doi.org/10.1111/j.1754-9434.2007.0002.x

Matthews, G., Zeidner, M., \& Roberts, R. D. (2002). Emotional intelligence. Cambridge, MA: The MIT Press.

Mayer, J. D., Salovey, P., \& Caruso, D. R. (2000). Models of emotional intelligence. In R. J. Sternberg (Ed.), Handbook of intelligence. Cambridge, UK: Cambridge University Press.

Mayer, J. D., Salovey, P., \& Caruso, D. R. (2004). Emotional intelligence: Theory, findings, and applications. Psychological Inquiry, 15(3), 197-215. http://dx.doi.org/10.1207/s15327965pli1503_02

Petrides, K. V., \& Furnham, A. (2000). On the dimensional structure of emotional intelligence. Personality and Individual Differences, 29(2), 313-320. http://dx.doi.org/10.1016/S0191-8869(99)00195-6

Rothbard, N. P. (2001). Enriching or depleting? The dynamics of engagement in work and family roles. Administrative Science Quarterly, 46(A), 655-684.

Saklofske, D. H., Austin, E. J., \& Minski, P. S. (2003). Factor structure and validity of a trait emotional intelligence measure. Personality and Individual Differences, 34(4), $707-721$. http://dx.doi.org/10.1016/S0191-8869(02)00056-9

Salovey, P., \& Mayer, J. D. (1990). Emotional intelligence. Imagination, Personality, and Cognition, 9(3), 185-211.

Salovey, P., Woolery, A., \& Mayer, J. D. (2002). Emotional intelligence: Conceptualization and measurement. In G. J. O. Fletcher \& M. S. Clark (Eds.), Blackwell handbook of social psychology: Interpersonal Processes (pp. 279-307): Blackwell Publishing.

Schaufeli, W., \& Bakker, A. B. (2004). Job demands, job resources, and their relationship with burnout and engagement: a multi-sample study. Journal of Organizational Behavior, 25(3), $293-315$. http://dx.doi.org/10.1002/job.248

Schaufeli, W., Bakker, A. B., \& Salanova, M. (2006). The measurement of work engagement with a short questionnaire: A cross-national study. Educational and Psychological Measurement, 66(4), 701-716. http://dx.doi.org/10.1177/0013164405282471

Schaufeli, W., Salanova, M., Gonzalez-Roma, V., \& Bakker, A. B. (2002). The measurement of burnout and engagement: a confirmatory factor analytic approach. Journal of Happiness Studies, 3(1), 71-92. http://dx.doi.org/10.1023/A:1015630930326

Schutte, N. S., Malouff, J. M., Hall, L. E., Haggerty, D. J., Cooper, J. T., Golden, C. J., \& Dornheim, L. (1998). Development and validation of a measure of emotional intelligence. Personality and Individual Differences, 25, 167-177. http://dx.doi.org/10.1016/S0191-8869(98)00001-4

Seligman, M. E. P., \& Csikszentmihalyi, M. (2000). Positive psychology: An introduction. American 
Psychologist, 55(1), 5-14. http://dx.doi.org/10.1037/0003-066X.55.1.5

Van Rooy, D. L., \& Viswesvaran, C. (2004). Emotional intelligence: a meta-analytic investigation of predictive validity and nomological net. Journal of Vocational Behavior, 65(1), 71-95. http://dx.doi.org/10.1016/S0001-8791(03)00076-9

Table 1. Demographic Profile and Rational Profile

\begin{tabular}{|c|c|c|c|c|}
\hline & Factors & Category & No of Respondents & Percentage \\
\hline \multirow[t]{9}{*}{1.} & \multirow[t]{9}{*}{ MNC They Work } & TCS & 32 & 26.9 \\
\hline & & CTS & 13 & 10.9 \\
\hline & & $\mathrm{HCL}$ & 14 & 11.8 \\
\hline & & $\mathrm{HP}$ & 16 & 13.4 \\
\hline & & SATYAM & 10 & 8.4 \\
\hline & & POLARIS & 11 & 9.2 \\
\hline & & SUTHERLAND & 11 & 9.2 \\
\hline & & FORD I T & 7 & 5.9 \\
\hline & & FLEXTRONICS & 5 & 4.2 \\
\hline \multirow[t]{4}{*}{2.} & \multirow[t]{4}{*}{ Shift Timings } & Morning & 6 & 5.0 \\
\hline & & General & 55 & 46.2 \\
\hline & & Noon & 34 & 28.6 \\
\hline & & Night & 24 & 20.2 \\
\hline \multirow[t]{2}{*}{3.} & \multirow[t]{2}{*}{ Gender } & Female & 24 & 20.2 \\
\hline & & Male & 95 & 79.8 \\
\hline \multirow[t]{4}{*}{4.} & \multirow[t]{4}{*}{ Age } & $18-24$ & 51 & 42.9 \\
\hline & & $25-30$ & 40 & 33.6 \\
\hline & & $31-40$ & 24 & 20.2 \\
\hline & & $41-50$ & 4 & 3.4 \\
\hline \multirow[t]{7}{*}{5.} & \multirow[t]{7}{*}{ Highest level of education } & U. G. Arts & 17 & 14.3 \\
\hline & & U. G. Science & 19 & 16.0 \\
\hline & & U. G. Engineering & 45 & 37.8 \\
\hline & & P. G. Arts & 10 & 8.4 \\
\hline & & P. G. Science & 18 & 15.1 \\
\hline & & P. G. Engineering & 7 & 5.9 \\
\hline & & Others & 3 & 2.5 \\
\hline \multirow[t]{3}{*}{6.} & \multirow[t]{3}{*}{ Marital status } & Single & 77 & 64.7 \\
\hline & & Married & 41 & 34.5 \\
\hline & & Divorced & 1 & .8 \\
\hline \multirow[t]{6}{*}{7.} & \multirow[t]{4}{*}{ Current occupation } & $\begin{array}{l}\text { IT - Software } \\
\text { Engineer }\end{array}$ & 32 & 26.9 \\
\hline & & IT - Trainer & 19 & 16.0 \\
\hline & & IT - Manager & 16 & 13.4 \\
\hline & & ITeS - CSE & 40 & 33.6 \\
\hline & & ITeS - Trainer & 7 & 5.9 \\
\hline & & ITeS - Manager & 5 & 4.2 \\
\hline \multirow[t]{5}{*}{8.} & \multirow{5}{*}{$\begin{array}{l}\text { Experience in the Current } \\
\text { Organization }\end{array}$} & Less than 1 year & 32 & 26.9 \\
\hline & & 1 year & 15 & 12.6 \\
\hline & & 2 Years & 29 & 24.4 \\
\hline & & 3 Years & 16 & 13.4 \\
\hline & & more than 3 Years & 27 & 22.7 \\
\hline \multirow[t]{4}{*}{9.} & \multirow{4}{*}{$\begin{array}{l}\text { Total no. of hours spend at } \\
\text { work place on daily basis }\end{array}$} & $5-6 \mathrm{hrs}$ & 8 & 6.7 \\
\hline & & $7-8 \mathrm{hrs}$ & 30 & 25.2 \\
\hline & & $9-10 \mathrm{hrs}$ & 66 & 55.5 \\
\hline & & More than $10 \mathrm{hrs}$ & 15 & 12.6 \\
\hline \multirow[t]{2}{*}{10.} & \multirow{2}{*}{$\begin{array}{l}\text { Total no. of hours spend on } \\
\text { commuting on daily basis }\end{array}$} & $30 \min$ & 34 & 28.6 \\
\hline & & $1-2 \mathrm{hrs}$ & 47 & 39.5 \\
\hline
\end{tabular}




\begin{tabular}{|c|c|c|c|c|}
\hline & & $2-3 \mathrm{hrs}$ & 27 & 22.7 \\
\hline & & $3-4 \mathrm{hrs}$ & 6 & 5.0 \\
\hline & & More than $4 \mathrm{hrs}$ & 5 & 4.2 \\
\hline \multirow[t]{5}{*}{11.} & \multirow[t]{5}{*}{ Mode of Commuting } & Bus & 22 & 18.5 \\
\hline & & Two- wheeler & 51 & 42.9 \\
\hline & & Car & 16 & 13.4 \\
\hline & & Train & 2 & 1.7 \\
\hline & & cab & 28 & 23.5 \\
\hline \multirow[t]{3}{*}{12.} & \multirow[t]{3}{*}{ Spouse Employment Detail } & Yes & 14 & 11.8 \\
\hline & & No & 27 & 22.7 \\
\hline & & Not Applicable & 78 & 65.5 \\
\hline \multirow[t]{5}{*}{13.} & \multirow{5}{*}{$\begin{array}{l}\text { How many children do you } \\
\text { have? }\end{array}$} & No child & 11 & 9.2 \\
\hline & & 1 & 17 & 14.3 \\
\hline & & 2 & 12 & 10.1 \\
\hline & & 3 & 1 & .8 \\
\hline & & Not Applicable & 78 & 65.5 \\
\hline \multirow[t]{5}{*}{14.} & \multirow{5}{*}{$\begin{array}{l}\text { Spouse spend at work for } \\
\text { paid employment }\end{array}$} & $0-4 \mathrm{hrs}$ & 12 & 10.1 \\
\hline & & $5-6 \mathrm{hrs}$ & 6 & 5.0 \\
\hline & & $7-8 \mathrm{hrs}$ & 11 & 9.2 \\
\hline & & $9-10 \mathrm{hrs}$ & 5 & 4.2 \\
\hline & & Not Applicable & 85 & 71.4 \\
\hline \multirow[t]{4}{*}{15.} & \multirow{4}{*}{$\begin{array}{l}\text { Please indicate the range in } \\
\text { which your } \mathrm{C} T \mathrm{~T} \text { falls }\end{array}$} & $100,001-200,000$ & 23 & 19.3 \\
\hline & & $200,001-300,000$ & 18 & 15.1 \\
\hline & & $300,001-400,000$ & 30 & 25.2 \\
\hline & & 400,001 and above & 48 & 40.3 \\
\hline
\end{tabular}

Table 2. Correlation

\begin{tabular}{|l|l|l|l|}
\hline \multicolumn{2}{|l|}{} & $\begin{array}{c}\text { Over all Emotional } \\
\text { Intelligence }\end{array}$ & $\begin{array}{c}\text { Over all Work } \\
\text { Engagement }\end{array}$ \\
\hline Over all Emotional Intelligence & Pearson Correlation & 1 & $.377(* *)$ \\
\hline & Sig. (2-tailed) & & .000 \\
\hline & N & 119 & 119 \\
\hline Over all Work Engagement & Pearson Correlation & $.377(* *)$ & 1 \\
\hline & Sig. (2-tailed) & .000 & 119 \\
\hline & N & 119 & 19 \\
\hline
\end{tabular}

** Correlation is significant at the 0.01 level (2-tailed).

Table 3. Emotional Intelligence Construct - Reliability Statistics

\begin{tabular}{|c|c|}
\hline Cronbach's Alpha & N of Items \\
\hline .907 & 29 \\
\hline
\end{tabular}

Table 4. Work Engagement Behavior - Reliability Statistics

\begin{tabular}{|c|c|}
\hline Cronbach's Alpha & N of Items \\
\hline .920 & 9 \\
\hline
\end{tabular}

Table 5. Chi-Square Tests

\begin{tabular}{|l|l|l|l|}
\hline & Value & Df & Asymp. Sig. (2-sided) \\
\hline Pearson Chi-Square & $37.186(\mathrm{a})$ & 20 & .011 \\
\hline Likelihood Ratio & 38.552 & 20 & .008 \\
\hline Linear-by-Linear Association & .871 & 1 & .351 \\
\hline N of Valid Cases & 119 & & \\
\hline
\end{tabular}

a 21 cells $(70.0 \%)$ have expected count less than 5 . The minimum expected count is .13 . 
Table 6. Oneway ANOVA

\begin{tabular}{|l|l|l|l|l|l|}
\hline & Sum of Squares & Df & Mean Square & F & Sig. \\
\hline Between Groups & 19.581 & 4 & 4.895 & 4.687 & .002 \\
Within Groups & 119.057 & 114 & 1.044 & & \\
Total & 138.639 & 118 & & & \\
\hline
\end{tabular}

Table 7. Post Hoc Tests: Multiple Comparisons

\begin{tabular}{|c|c|c|c|c|c|c|}
\hline $\begin{array}{l}\text { (I) For how many years } \\
\text { you are employed in the } \\
\text { current organization? }\end{array}$ & $\begin{array}{l}\text { (J) For how many years you } \\
\text { are employed in the current } \\
\text { organization? }\end{array}$ & $\begin{array}{l}\text { Mean } \\
\text { Difference } \\
(\mathrm{I}-\mathrm{J})\end{array}$ & $\begin{array}{l}\text { Std. } \\
\text { Error }\end{array}$ & Sig. & \multicolumn{2}{|c|}{$\begin{array}{l}95 \% \text { Confidence } \\
\text { Interval }\end{array}$} \\
\hline & & & & & $\begin{array}{l}\text { Lower } \\
\text { Bound }\end{array}$ & $\begin{array}{l}\text { Upper } \\
\text { Bound }\end{array}$ \\
\hline \multirow[t]{4}{*}{ Less than 1 year } & 1 year & -.338 & .320 & 1.000 & -1.25 & .58 \\
\hline & 2 Years & $.787(*)$ & .262 & .033 & .04 & 1.54 \\
\hline & 3 Years & .625 & .313 & .482 & -.27 & 1.52 \\
\hline & more than 3 Years & -.012 & .267 & 1.000 & -.78 & .75 \\
\hline \multirow[t]{4}{*}{1 year } & Less than 1 year & .338 & .320 & 1.000 & -.58 & 1.25 \\
\hline & 2 Years & $1.124(*)$ & .325 & .008 & .19 & 2.05 \\
\hline & 3 Years & .963 & .367 & .100 & -.09 & 2.01 \\
\hline & more than 3 Years & .326 & .329 & 1.000 & -.62 & 1.27 \\
\hline \multirow[t]{4}{*}{2 Years } & Less than 1 year & $-.787(*)$ & .262 & .033 & -1.54 & -.04 \\
\hline & 1 year & $-1.124(*)$ & .325 & .008 & -2.05 & -.19 \\
\hline & 3 Years & -.162 & .318 & 1.000 & -1.07 & .75 \\
\hline & more than 3 Years & $-.798(*)$ & .273 & .042 & -1.58 & -.02 \\
\hline \multirow[t]{4}{*}{3 Years } & Less than 1 year & -.625 & .313 & .482 & -1.52 & .27 \\
\hline & 1 year & -.963 & .367 & .100 & -2.01 & .09 \\
\hline & 2 Years & .162 & .318 & 1.000 & -.75 & 1.07 \\
\hline & more than 3 Years & -.637 & .322 & .508 & -1.56 & .29 \\
\hline \multirow[t]{4}{*}{ more than 3 Years } & Less than 1 year & .012 & .267 & 1.000 & -.75 & .78 \\
\hline & 1 year & -.326 & .329 & 1.000 & -1.27 & .62 \\
\hline & 2 Years & $.798(*)$ & .273 & .042 & .02 & 1.58 \\
\hline & 3 Years & .637 & .322 & .508 & -.29 & 1.56 \\
\hline
\end{tabular}

$*$ The mean difference is significant at the .05 level.

Table 8. Factor Analysis

KMO and Bartlett's Test

\begin{tabular}{|l|l|l|}
\hline Kaiser-Meyer-Olkin Measure of Sampling Adequacy. & .825 \\
\hline \multirow{2}{*}{$\begin{array}{l}\text { Bartlett's Test of } \\
\text { Sphericity }\end{array}$} & Approx. Chi-Square & 1713.127 \\
\cline { 2 - 3 } & Df & 406 \\
\cline { 2 - 3 } & Sig. & .000 \\
\hline
\end{tabular}

The Kaiser-Meyer-Olkin Measures of sampling adequacy of 0.825 shows that the variables and the sample size of 119 were viable and feasible to run a factor analysis. 
Total Variance Explained

\begin{tabular}{|c|c|c|c|c|c|c|c|c|c|}
\hline \multirow[t]{2}{*}{$\begin{array}{l}\text { Compo } \\
\text { nent }\end{array}$} & \multicolumn{3}{|c|}{ Initial Eigen values } & \multicolumn{3}{|c|}{$\begin{array}{l}\text { Extraction Sums of Squared } \\
\text { Loadings }\end{array}$} & \multicolumn{3}{|c|}{ Rotation Sums of Squared Loadings } \\
\hline & Total & $\begin{array}{l}\% \text { of } \\
\text { Variance }\end{array}$ & $\begin{array}{l}\text { Cumulative } \\
\%\end{array}$ & Total & $\begin{array}{l}\% \text { of } \\
\text { Variance }\end{array}$ & $\begin{array}{l}\text { Cumulative } \\
\%\end{array}$ & Total & $\begin{array}{l}\% \text { of } \\
\text { Variance }\end{array}$ & Cumulative $\%$ \\
\hline 1 & 9.175 & 31.638 & 31.638 & 9.175 & 31.638 & 31.638 & 4.065 & 14.018 & 14.018 \\
\hline 2 & 2.534 & 8.738 & 40.377 & 2.534 & 8.738 & 40.377 & 3.811 & 13.141 & 27.159 \\
\hline 3 & 1.783 & 6.148 & 46.525 & 1.783 & 6.148 & 46.525 & 3.346 & 11.539 & 38.698 \\
\hline 4 & 1.529 & 5.274 & 51.799 & 1.529 & 5.274 & 51.799 & 2.044 & 7.049 & 45.748 \\
\hline 5 & 1.433 & 4.943 & 56.741 & 1.433 & 4.943 & 56.741 & 2.002 & 6.904 & 52.652 \\
\hline 6 & 1.265 & 4.361 & 61.102 & 1.265 & 4.361 & 61.102 & 1.694 & 5.841 & 58.493 \\
\hline 7 & 1.177 & 4.058 & 65.161 & 1.177 & 4.058 & 65.161 & 1.558 & 5.373 & 63.866 \\
\hline 8 & 1.120 & 3.861 & 69.022 & 1.120 & 3.861 & 69.022 & 1.495 & 5.156 & 69.022 \\
\hline 9 & .952 & 3.282 & 72.304 & & & & & & \\
\hline 10 & .802 & 2.765 & 75.069 & & & & & & \\
\hline 11 & .735 & 2.535 & 77.603 & & & & & & \\
\hline 12 & .693 & 2.389 & 79.993 & & & & & & \\
\hline 13 & .605 & 2.086 & 82.079 & & & & & & \\
\hline 14 & .578 & 1.992 & 84.071 & & & & & & \\
\hline 15 & .563 & 1.942 & 86.013 & & & & & & \\
\hline 16 & .467 & 1.611 & 87.624 & & & & & & \\
\hline 17 & .444 & 1.530 & 89.153 & & & & & & \\
\hline 18 & .419 & 1.444 & 90.598 & & & & & & \\
\hline 19 & .379 & 1.308 & 91.906 & & & & & & \\
\hline 20 & .345 & 1.188 & 93.094 & & & & & & \\
\hline 21 & .338 & 1.166 & 94.260 & & & & & & \\
\hline 22 & .275 & .949 & 95.210 & & & & & & \\
\hline 23 & .266 & .916 & 96.126 & & & & & & \\
\hline 24 & .243 & .839 & 96.964 & & & & & & \\
\hline 25 & .227 & .784 & 97.748 & & & & & & \\
\hline 26 & .201 & .695 & 98.442 & & & & & & \\
\hline 27 & .171 & .589 & 99.031 & & & & & & \\
\hline 28 & .159 & .547 & 99.578 & & & & & & \\
\hline 29 & .122 & .422 & 100.000 & & & & & & \\
\hline
\end{tabular}

Extraction Method: Principal Component Analysis. 
Rotated Component Matrix (a)

\begin{tabular}{|c|c|c|c|c|c|c|c|c|}
\hline & \multicolumn{8}{|c|}{ Component } \\
\hline & 1 & 2 & 3 & 4 & 5 & 6 & 7 & 8 \\
\hline $\begin{array}{l}\text { I know when to speak about my personal } \\
\text { problems to others }\end{array}$ & -.045 & .443 & .109 & .674 & .072 & -.119 & -.137 & -.121 \\
\hline $\begin{array}{l}\text { When I am faced with obstacles, I remember } \\
\text { times I faced similar obstacles and overcame } \\
\text { them }\end{array}$ & .105 & .626 & .278 & .390 & -.055 & -.162 & -.122 & -.123 \\
\hline I expect that I will do well on most things I try & .321 & .686 & .200 & .238 & .075 & .027 & .074 & -.058 \\
\hline Other people find it easy to make known in me & .289 & $\overline{.536}$ & -.046 & .220 & -.020 & .336 & .196 & .190 \\
\hline $\begin{array}{l}\text { Some of the major events of my life have led me } \\
\text { to re-evaluate what is important and not } \\
\text { important }\end{array}$ & -.009 & .710 & -.020 & .015 & .221 & -.171 & .274 & -.088 \\
\hline $\begin{array}{l}\text { Emotions are one of the things that make my life } \\
\text { worth living }\end{array}$ & .149 & .736 & -.122 & -.164 & -.017 & .222 & .079 & .214 \\
\hline I am aware of my emotions as I experience them & .308 & .674 & .162 & .090 & .081 & .148 & .116 & -.078 \\
\hline I expect good things to happen & .171 &. & .308 & .026 & -.057 & .054 & -.318 & -.003 \\
\hline I like to share my emotions with others & .054 & $\overline{.113}$ & .105 & -.046 & .040 & .839 & -.147 & -.029 \\
\hline $\begin{array}{l}\text { When I experience a positive emotion, I know } \\
\text { how to make it last }\end{array}$ & .285 & .217 & .530 & .235 & .075 & -.264 & .133 & .095 \\
\hline I arrange events others enjoy & .223 & .172 & .281 & -.075 & .321 & .255 & .251 & -.434 \\
\hline I seek out activities that make me happy & 317 & .142 & .513 & .253 & .340 & .080 & .003 & -.238 \\
\hline $\begin{array}{l}\text { I am aware of the non-verbal messages I send to } \\
\text { others }\end{array}$ & .161 & .024 & $\underline{.835}$ & .072 & .115 & .097 & .117 & .172 \\
\hline $\begin{array}{l}\text { I present myself in a way that makes a good } \\
\text { impression on others }\end{array}$ & .531 & .173 & .565 & -.007 & -.222 & .169 & -.064 & .115 \\
\hline $\begin{array}{l}\text { When I am in a positive mood, solving problems } \\
\text { is easy for me }\end{array}$ & .522 & .294 & .424 & .150 & .157 & -.155 & -.075 & -.239 \\
\hline $\begin{array}{l}\text { By looking at their facial expressions, I } \\
\text { recognize the emotions people are experiencing }\end{array}$ & .069 & .102 & .741 & .038 & .251 & .156 & .239 & -.097 \\
\hline I know why my emotions change & .146 & .151 & .271 & .111 & .069 & -.173 & .757 & -.022 \\
\hline $\begin{array}{l}\text { When I am in a positive mood, I am able to come } \\
\text { up with new ideas }\end{array}$ &. .572 & .253 & .228 & .197 & .398 & .115 & -.227 & -.197 \\
\hline I have control over my emotions & .450 & .103 & .405 & .192 & -.203 & .229 & .392 & .124 \\
\hline $\begin{array}{l}\text { I easily recognize my emotions as I experience } \\
\text { them }\end{array}$ & .701 & .201 & .192 & -.201 & -.131 & .060 & .305 & .010 \\
\hline $\begin{array}{l}\text { I motivate myself by imagining a good outcome } \\
\text { to tasks I take on }\end{array}$ & .696 & .122 & .097 & .057 & .296 & -.083 & .023 & -.208 \\
\hline $\begin{array}{l}\text { I compliment others when they have done } \\
\text { something well }\end{array}$ & .223 & .036 & .380 & .255 & .296 & .444 & .399 & -.166 \\
\hline $\begin{array}{l}\text { I am aware of the non-verbal messages other } \\
\text { people send }\end{array}$ & $\underline{.505}$ & .284 & .262 & .298 & .298 & -.095 & .138 & .070 \\
\hline $\begin{array}{l}\text { When another person tells me about an important } \\
\text { event in his or her life, I almost feel as though I } \\
\text { have experienced this event myself }\end{array}$ & .255 & .097 & .123 & -.003 &. .807 & -.021 & -.010 & .074 \\
\hline $\begin{array}{l}\text { I know what other people are feeling just by } \\
\text { looking at them }\end{array}$ & .158 & -.112 & .265 & .320 &. .566 & .373 & .208 & .207 \\
\hline $\begin{array}{l}\text { I help other people feel better when they are } \\
\text { down }\end{array}$ & .647 & .196 & .007 & .356 & .098 & .192 & .085 & .111 \\
\hline $\begin{array}{l}\text { I use good moods to help myself keep trying in } \\
\text { the face of obstacles }\end{array}$ & .728 & .129 & .174 & .010 & .255 & .103 & .030 & .013 \\
\hline $\begin{array}{l}\text { I can tell how people are feeling by listening to } \\
\text { the tone of their voice }\end{array}$ & .170 & -.002 & .122 & .786 & .055 & .078 & .228 & -.028 \\
\hline $\begin{array}{l}\text { It is difficult for me to understand why people } \\
\text { feel the way they do }\end{array}$ & -.027 & .053 & .144 & -.093 & .136 & .011 & .014 & $\underline{.900}$ \\
\hline
\end{tabular}


Table 9. Regression Analysis

Model Summary

\begin{tabular}{|l|l|l|l|l|}
\hline Model & R & R Square & Adjusted R Square & Std. Error of the Estimate \\
\hline 1 & $.439(\mathrm{a})$ & .192 & .185 & 1.17482 \\
\hline 2 & $.502(\mathrm{~b})$ & .252 & .239 & 1.13528 \\
\hline 3 & $.537(\mathrm{c})$ & .289 & .270 & 1.11196 \\
\hline 4 & $.569(\mathrm{~d})$ & .324 & .300 & 1.08910 \\
\hline 5 & $.589(\mathrm{e})$ & .347 & .318 & 1.07477 \\
\hline
\end{tabular}

ANOVA (f)

\begin{tabular}{|l|l|l|l|l|l|l|}
\hline Model & & Sum of Squares & Df & Mean Square & F & Sig. \\
\hline 5 & Regression & 69.418 & 5 & 13.884 & 12.019 & $.000(\mathrm{e})$ \\
\hline & Residual & 130.529 & 113 & 1.155 & & \\
\hline & Total & 199.947 & 118 & & & \\
\hline
\end{tabular}

Coefficients (a)

\begin{tabular}{|l|l|l|l|l|l|l|}
\hline Model & & \multicolumn{2}{|l|}{$\begin{array}{l}\text { Unstandardized } \\
\text { Coefficients }\end{array}$} & $\begin{array}{l}\text { Standardized } \\
\text { Coefficients }\end{array}$ & $\mathrm{t}$ & Sig. \\
\hline 5 & & $\mathrm{~B}$ & Std. Error & Beta & & \\
\hline & (Constant) & 1.379 & .704 & & 1.959 & .053 \\
\hline & $\begin{array}{l}\text { When I experience a positive emotion, I } \\
\text { know how to make it last }\end{array}$ & .428 & .104 & .357 & 4.106 & .000 \\
\hline & I arrange events others enjoy & .272 & .082 & .281 & 3.327 & .001 \\
\hline & $\begin{array}{l}\text { I am aware of the non-verbal messages other } \\
\text { people send }\end{array}$ & .352 & .107 & .301 & 3.297 & .001 \\
\hline & I expect good things to happen & -.242 & .086 & -.236 & -2.824 & .006 \\
\hline & $\begin{array}{l}\text { I know what other people are feeling just by } \\
\text { looking at them }\end{array}$ & -.156 & .077 & -.178 & -2.015 & .046 \\
\hline
\end{tabular}

Dependent Variable: overall Work Engagement

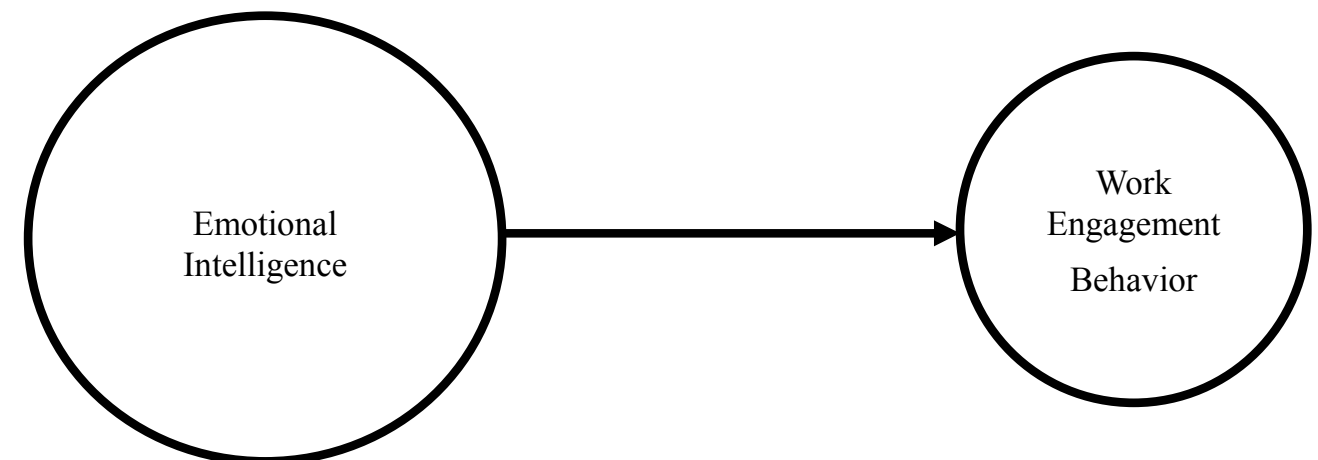

Schutte Self-Report Inventory (SSRI)

(Schutte et al, 1998)
Utrecht Work Engagement Scale (UWES)

(Schaufeli et al., 2006)

Figure 1. Proposed Conceptual Model 